\title{
Towards Improved Performance in Marketing: The Use of Property-based websites by Estate Surveyors and Valuers in Lagos, Nigeria
}

\author{
Adeyemi O. Bamidele ${ }^{1}$, Rotimi D. Adenusi ${ }^{2}$, and Temidayo O. Osunsanmi ${ }^{3}$ \\ 1,2 Department of Estate Management University of Lagos, Nigeria \\ ${ }^{3}$ Sustainable Human Settlement and Construction Research Centre, Faculty of Engineering and the Built \\ Environment, University of Johannesburg, South Africa
}

To cite this article: Bamidele, A.O., Adenusi, R. D., \& Osunsanmi, T.O. (2018). Towards Improved Performance in Marketing: The Use of Property-Based Websites by Estate Surveyors and Valuers in Lagos, Nigeria. Journal of African Real Estate Research, 3(1), pp.81-93. DOI: 10.15641/jarer.v1i1.451.

\begin{abstract}
:
The increase in globalisation has changed marketing strategies available to professionals within the built environment. This study investigated the marketing methods most used in Lagos' metropolis. It assessed the extent to which estate surveyors and valuers in Nigeria have adopted property-based websites for the marketing of their real estate services. A random sampling method was used to obtain data from 82 estate surveyors and valuers within Lagos' metropolis. The data were analysed with SPSS V24 (statistical software), using Friedman's Test and OneWay Analysis of Variance (ANOVA). The study concluded that conventional/traditional methods of marketing dominate the marketing activities of estate surveyors and valuers, weakening agency practice in Nigeria in relation to the current global context.
\end{abstract}

Keywords: Agency; Estate Surveyors and Valuers; Marketing; Property-based Websites; Real Estate

\section{Introduction}

Agboola et al. (2010) affirmed that real estate agency is one of the most multifaceted aspects of the estate surveying and valuation profession in Nigeria. Marketing could be simply defined as the activities or processes involved in promoting, selling and distributing a good or service (Skitmore \& Smyth, 2006; Yankah \& Dadzie 2015). Therefore, in order to thrive in real estate agency, the role of marketing cannot be underestimated (as could be the case of any other product), as marketing plays a major role in reaching out to prospective customers or clients and the eventual consummation of the real estate transaction. 
In today's business world, the success of any business organisation depends largely on how best the organisation can reach and satisfy its customers. This places tremendous responsibility on any firm or organisation intending to excel by way of marketing (Ayedun et al., 2014). Previously, marketers had depended on broadcast or print media as well as press releases. These methods have since been found to be expensive with minimal success (Scott, 2013). This created the need for a change in the marketing platforms of business activities. The World Wide Web provides a tremendous opportunity to marketers to reach buyers directly with targeted information at a fraction of their previous marketing budget (McDonagh, 2006). Kotler and Armstrong (2012) noted that much of the world's marketing activity is therefore currently carried out over digital networks which connect people and companies.

As a result of globalisation and the world becoming a global village, the conventional methods of communication with clients and customers have changed significantly. The emergence of the World Wide Web has increased use of the internet and websites amongst several professionals and industries (Ley, 2015; Rogers \& Koh, 2017). Today, professionals are utilising/optimising different electronic platforms to reach out to their targeted clients, thus increasing awareness of their services. In line with this current trend, there are several property-based websites which are available for the estate surveyors and valuers (ESVs). These platforms allow professionals to market real estate and reach out to numerous potential clients (Agboola et al., 2010). Unfortunately, Oni and Adebayo (2012) and Oni (2013) observed that ESVs who are expected to adopt the use of information technology have not yet done so, as many of the property-based websites require token payments before they could be used. Access to only a limited number of these websites is free.

In Nigeria, the Estate Surveyors and Valuers Board of Nigeria (ESVARBON) Decree No 24 of 1975, prohibits estate surveyors and valuers from advertising their services in print media (e.g. dailies), except with the approval of, and in line with the guidance set by, the ESVARBON. In accordance with the stipulations, various strategies or methods for the use of ESVs for the marketing of real estate include regulations regarding: boards (To Let/For Sale), property bulletin/handout, event marketing, personal contacts and property magazines. This has hindered the marketing of real estate services within the country, preventing Nigerian-based companies from competing effectively within the globalised world (Olukolajo, et al., 2015).

Moreover, one crucial aspect of the estate surveying and valuation profession which has continued to attract considerable attention in Nigeria is the practice of real estate. On this premise, researchers like Araloyin and Ojo (2011); Iroham et al. (2012); Oni and Adebayo (2012) and Oni (2013), amongst others, have investigated issues relating to this practice particularly within metropolitan Lagos. If real estate agency in Nigeria is to be stimulated and sustained, the extent to which ESVs have responded to the use of propertybased websites thus far demands further research attention (Olukolajo, et al., 2015). 
Currently, there have been relatively few studies which have addressed the use of property-based websites for marketing amongst ESVs in Nigeria. This research study attempted to address this research gap through investigating the following research questions: Which of the traditional methods for marketing real estate are still predominantly used by ESVs with Lagos' metropolis? How conscious are Lagos' metropolitan ESVs regarding property-based websites for the marketing of real estate? Which of the property-based websites for marketing real estate is most widely used amongst ESVs, if any?

\section{Literature Review}

\section{Agency Practice in Real Estate Market}

The real estate market is the mechanism through which potential buyers and sellers of real estate meet to exchange real estate related information and purchases (Bond et al., 2000). Due to the intrinsic characteristics of real estate, there is no specific location for this exchange. Kvedaraviciene (2009) avowed that the major activities of the real estate market include development/construction, financing, valuation, agency/brokerage, property acquisition, sale, letting and property management. Ayedun et al. (2014) affirmed that among all the activities occurring in the real estate market, agency is the most practised as it guarantees high return on invested capital, is less risky and integrates participants to achieve a common goal.

Agency practice entails bringing together parties of divergent interests to achieve specific goals (Iroham et al., 2012). The goal varies among parties with the parties' relationship with the agent controlled by different regulatory framework (Agboola et al., 2010). Olukolajo et al. (2015) uphold that the weak regulatory framework for agency practice has allowed other professionals in the built environment to assume this duty.

\section{Marketing: Steps in a Real Estate Agency Transaction Process}

Information is the key to success in real estate business. In support of this assertion, James et al. (2000) affirmed that agents connect buyers to sellers, or lessors to lessees, through the control and dissemination of information provided to them by both parties. Crowston and Wigand (1999) opined that real estate surveyors and valuers are pure market intermediaries who form this connection. These individuals are valued for the information and skills they bring to make both listings and sales possible. According to Crowston and Wigand (1999), the real estate transaction process is divided into five distinct stages, which are: Enlisting, Searching, Evaluating, Negotiating and Execution. However, literature such as; Skitmore and Smyth (2006); McDonagh (2006); Kvedaraviciene (2009) and Ley (2015) uphold that these marketing steps vary depending on the nature of the market and the economy. Below is an overview of the stages in the process in the context of the current Nigerian real estate market.

\section{Stage 1: Enlisting}


Firstly, potential sellers or lessors of real estate liaise with ESVs to help put real estate in the market. ESVs by virtue of their training are charged with the responsibility of determining how to position the property (e.g. which features to emphasise or if some repairs should be made, and how to price it) (Araloyin \& Olatoye, 2011). Real estate properties are then advertised for sale or lease. For the purpose of sales, listing usually requires the seller to pay the appointed estate surveyor and valuer a commission once the house is sold. Since ESVs control the listing and dissemination of this information, this seems to resemble a monopolistic or cartel-like structure in terms of information ownership.

\section{Stage 2: Searching}

Ley (2015) reported that majority of potential buyers or lessees review houses through their agent to find those that might be suitable (in location, size, price, features, etc.). Information on available houses comes from many sources, where buyers/lessees could look in property magazines or inquire through $T o$ Let/For Sale boards erected outside properties in the areas they are interested in. Due to the evolution of property-based websites, a buyer/lessee could first conduct an independent search for property and thereafter seek the professional advice of an estate surveyor and valuer regarding which features are important or which neighbourhoods to consider (Schulte et al., 2005).

\section{Stage 3: Evaluation}

At this stage, the most promising real estate is further appraised. Typically, this evaluation is done in person during a walk-through inspection of the property by the would-be buyer or lessee. Baldi (2013) emphasised that the importance of this stage is the key difference between real estate and most other goods. This is because the prospective buyer or lease is usually given the opportunity to view and feel the product before purchase or lease.

\section{Stage 4: Negotiation}

After a desirable house is identified, the potential buyer or lessee makes an offer to purchase or rent the house at a price. This price is usually contingent on various of factors, such as available finances, having the house inspected, neighbourhood infrastructure and many others. Often, a buyer or lessee is advised on the price to offer or on other points of negotiating strategies by the estate surveyor and valuer. The seller or lessor's agent may receive a significant number of offers or make a counter-offer to the potential buyers/lessees. For purchase, and in some instances lease, a title search is done by the buyer to ascertain that the interest which exists in the subject property is genuine (Yankah \& Dadzie, 2015). Thereafter the buyer and seller, or lessor and lessee, will agree to a binding contract, either for a sale or lease in any given case. At this point, the services of a lawyer might be required to address/amend the contingencies within the contract according to the buyer/seller or lessor/lessee agreement.

\section{Stage 5: Execution}


Ley (2015) suggested that this is the last stage of marketing characterised by the resolving of contractual issues between potential buyer and valuer. Iroham et al. (2012) and Bobenko (2013) affirmed that professional malpractice, on the part of the estate surveyor and valuer during payment, often characterises this stage.

\section{The Shift in Real Estate Marketing}

The consistent growth of commerce on the internet has attracted substantial interest (Bobenko, 2013). Since the internet is a public network and increasingly ubiquitous, it conveniently addresses the problem of connectivity between potential trading partners and extends even to the general consumer (Crowston \& Wigand, 1999). The internet can attract the attention of the global population and has impacted the way business is being conducted today. In light of this, real estate marketing is gradually moving away from the conventional methods of advertising (such as To Let/For Sale boards, property bulletins or handouts, personal contacts, property magazines) to the use of the World Wide Web via property-based websites (Rogers \& Koh, 2017). This has helped the facilitation and dissemination of available information to millions of people at the same time. Benjamin and Chinloy (1995) concluded that sellers who adopt this technology would achieve higher sales in shorter time periods. Thrall (1998) also predicted that prospective home buyers would be able to search properties using filters such as style, features and amenities. Furthermore, it allows users to obtain location information for the targeted property and surrounding community online. James et al. (2000) categorised the two types of information gathered from the internet as; information related to property brokers or companies themselves, and information regarding the specific properties available for purchase or lease.

Baen and Guttery (1997) and Bond et al. (2000) have shown that the quality and quantity of information available online is steadily increasing, much of it due to the advances of technology that make it easier to gather and upload data. Brokers have affordable means of promoting themselves and their listings. The internet allows buyers to search at their convenience and pace, learning a great deal before they begin any actual negotiations. Sellers can now more easily see other homes in the area and can be better informed. Bond et al. (2000) argued that brokerage firms who operate without listing their properties on a website and attempt to remain current with developments in the future do so at significant economic risk. Bobenko (2013), in an article on a comprehensive approach to selling real estate, reported that the internet has had a significant influence on the real estate industry in America as buyers can go online to research listings and related information and are well informed by the time they contact a real estate agent. The following universal internet Real Estate Statistics have been highlighted;

a) Over $90 \%$ of buyers use the internet at some point during the home buying process.

b) $75 \%$ of buyers first saw the property they eventually purchased online. 
c) Real estate related Google searches are up by $253 \%$ over the past four years.

d) Online advertising is 20 times more likely to sell a property than print advertising.

e) Internet buyers only look at an average of seven properties on their first tour of the physical properties of interest (Cherif, 2013).

In the same vein, a survey conducted by the California Association of Realtors (2013) on home buyers in California revealed that almost all home buyers used the internet in the process of home buying; and despite the fact that home searches through agents increased in 2013, the percentage of home searchers through online platforms doubled from the initial 16\% in 2012 to $37 \%$ in 2013. Unfortunately, there is currently no database within the Nigerian context showing the impact of these platforms on real estate marketing, which further informed the need for this current study.

\section{Methodology}

Lagos' metropolis was identified as the study area. Lagos State was conceived as the most suitable area for the study for diverse reasons. It has remained the heart of commercial and industrial activities and has absorbed a diverse national population over the years (Ajayi et al., 2016). This has continually prompted the need for Estate Surveying and Valuation services in the state. Babawale (2011) asserted that despite the shift in base of the Federal Government in Nigeria from Lagos to Abuja, Lagos' metropolis has continued to be the centre of the country's most active property market. Thus, registered firms of ESVs located within Lagos metropolis were identified as the study and sample area.

The respondents within the identified population were selected through random sampling. The study adopted random sampling as it allows one to generate a smaller sample size from a larger population with the intention of generalising about the larger group (Kumar, 2011). Creswell (2009) reported that random sampling works on the concept of obtaining a comprehensive list of a larger population and randomly selecting individuals to be adopted for the sample. The concept behind random sampling makes it suitable for this study due to the large number of estate firms in Lagos, totalling 400 (NIESV, 2009), of which about 270 of them are in Lagos' metropolis (Iroham et al., 2014). Therefore, 100 ESVs known for agency practice in the proximity of the research were randomly selected. Out of the selected professionals, 82 responded satisfactorily, showing consistency in their response.

The study adopted a quantitative research methodology as it enables one to gather, assemble and analyse data in a numerical format using mathematical methods. Additionally, this methodology generalises the findings across a larger group of specific people (Blaikie, 2010). The quantitative data was analysed by adopting the Statistical Package for Social Science (SPSS) version 24 using descriptive statistics such as mean item score and frequencies. This was supported with ANOVA (One Way Analysis of 
Variance) to test whether a significant difference is present between the adoption of contemporary and conventional modes of marketing.

\section{Results and Discussion}

\section{Characteristics of Respondents}

Table 1 presents the general characteristics of the respondents. Table 1 reveals that more than half $(56.1 \%)$ of the respondents were male and $43.9 \%$ were female, which could imply that estate surveying and valuating is a male dominated field within the Lagos metropolitan area.

\section{Table 1: Characteristics of Respondents}

\begin{tabular}{|l|l|l|}
\hline Characteristics & Frequency & Percentage (\%) \\
\hline Gender & & \\
\hline Male & 46 & 56.1 \\
\hline Female & 36 & 43.9 \\
\hline Total & $\mathbf{8 2}$ & $\mathbf{1 0 0}$ \\
\hline Age group & & \\
\hline $18-25$ & 25 & 30.5 \\
\hline $26-35$ & 38 & 46.3 \\
\hline $35-45$ & 12 & 14.6 \\
\hline 46 above & 7 & 8.5 \\
\hline Total & $\mathbf{8 2}$ & $\mathbf{1 0 0}$ \\
\hline Academic qualification & & \\
\hline ND & 6 & 7.3 \\
\hline BSc/HND & 51 & 62.2 \\
\hline MSc & 25 & 30.5 \\
\hline Total & $\mathbf{8 2}$ & $\mathbf{1 0 0}$ \\
\hline Professional qualification & & \\
\hline Graduate member & 14 & 17.5 \\
\hline Probationer member & 12 & 14.6 \\
\hline Associate member & 48 & 58.5 \\
\hline Fellow & 8 & 9.8 \\
\hline Total & $\mathbf{5 0}$ & $\mathbf{1 0 0}$ \\
\hline Working Experience & & \\
\hline $1-5$ & 16 & 19.5 \\
\hline 6-10 & 49 & 59.8 \\
\hline 11-15 & 15 & 18.3 \\
\hline 16 above & 2 & 2.4 \\
\hline Total & $\mathbf{8 2}$ & $\mathbf{1 0 0}$ \\
\hline & & \\
\hline & & \\
\hline
\end{tabular}

Table 1 shows that, at the time of this study, $62.2 \%$ of the respondents were either Bachelor of Science (BSc) or Higher National Diploma (HND) holders, $30.5 \%$ had studied up to Master in Science (MSc) level and 7.3\% were National Diploma (HND) holders. It could be inferred that BSc and HND's comprised the majority of respondents' qualifications. Professional qualifications with NIESV/ESVARBON shows that $17.1 \%$ were graduate members, $58.5 \%$ were associate members, $14.6 \%$ were probationers and $9.8 \%$ were fellows. This suggests that all the respondents had different professional membership statuses in accordance with the stipulations of the NIESV and ESVARBON at the time of this study. Table 1 also depicts that 
all the respondents had gained sufficient work experience; $59.8 \%$ had worked between $6-10$ years, $19.5 \%$ within $1-5$ years, $18.3 \%$ between $11-15$ years and the rest $(2.4 \%)$ had worked for 16 years or more.

\section{Area of Specialization of Respondents}

Table 2 presents the area of specialisation of the respondents. It was found that the majority of respondents specialised in estate agency, property management, property valuation and appraisal, with only $36.6 \%$ specializing in development. This implies that ESVs within the study area rarely specialise in property development, while a major concentration is seen in other areas of the estate surveying profession.

Table 2: Area of Specialization

\begin{tabular}{|l|l|l|}
\hline Specialization & Specialized (\%) & Not specialized (\%) \\
\hline Estate agency & $82(100 \%)$ & - \\
\hline Property management & $82(100 \%)$ & - \\
\hline Property valuation & $82(100 \%)$ & - \\
\hline Development & $30(36.6 \%)$ & $52(63.4 \%)$ \\
\hline Appraisal & $82(100 \%)$ & - \\
\hline
\end{tabular}

\section{Conventional Ways of Marketing Real Estate}

Table 3 presents the ranking of the use of conventional methods of marketing real estate. Respondents rated the frequency of usage on a 5-point Likert Scale from 1 to 5 where 1 denoted not at all and 5 represented very often.

Table 3: Conventional Methods of Marketing Real Estate

\begin{tabular}{|l|l|l|}
\hline Conventional Methods & Mean Score & Rank \\
\hline To Let/For Sale board & 4.70 & 1 \\
\hline Referral & 4.51 & 2 \\
\hline Personal contact & 4.32 & 3 \\
\hline Property bulletin & 4.05 & 4 \\
\hline Property magazine & 3.91 & 5 \\
\hline Event marketing & 2.90 & 6 \\
\hline
\end{tabular}

Table 3 shows that "To Let/For Sale" board is the conventional method mostly used for marketing real estate (mean score is 4.70 ); followed by referrals and personal contact. Property bulletins, property magazines and events marketing were the three least used conventional marketing methods reported by respondents. Table 3 indicates a high mean score attributed to all the conventional methods for marketing, implying that the ESVs within the study area predominantly use conventional methods of marketing. The use of property bulletins is reportedly outdated but allows for the collaboration of firms in the area through joint marketing (Olukolajo et al., 2015). Scott (2013) asserted that marketers had previously depended on broadcast or print media as well as press releases, which are both expensive mediums with minimal assured success. Traditionally, Mangold and Faulds (2009) argued that methods such as sales promotions, public relations, personal selling and word 
of mouth could still be used by marketing agents to convey their services. However current tools and strategies of communication with prospective clients or customers have changed significantly since the emergence of internet-based platforms.

\section{Contemporary Methods of Marketing Real Estate}

Table 4 presents the awareness of the respondents regarding property-based websites for marketing real estate. Table 5 shows that almost all $(92.7 \%)$ of the respondents were aware of internet-based platforms, while the remainder of participants $(7.3 \%)$ were not aware.

Table 4: Awareness of Property-based websites

\begin{tabular}{|l|l|l|}
\hline Awareness & Frequency & Percentage \\
\hline Yes & 76 & 92.7 \\
\hline No & 6 & 7.3 \\
\hline Total & 82 & 100 \\
\hline
\end{tabular}

Furthermore, respondents were asked to rate the use of property-based websites for marketing real estate on a 5-point Likert Scale with 5 representing very often and 1 not at all. The ranking is presented in Table 5. From the table, it was revealed that 'Nigerian Property Centre' was the most used website by ESVs (ranked $1^{\text {st }}$ ). Followed by this were 'Lamudi' and 'Private Property'. The least (ranked $11^{\text {th }}$ ) was 'Mobo free'.

Table 5: Use of Property-based websites

\begin{tabular}{|l|l|l|}
\hline Property-based websites & Mean Score & Rank \\
\hline www.nigeriaproperty.centre & 3.87 & 1 \\
\hline www.lamudi.com.ng & 3.44 & 2 \\
\hline www.privateproperty.com.ng & 3.41 & 3 \\
\hline www.castles.com.ng & 3.33 & 4 \\
\hline www.property24.com.ng & 2.99 & 5 \\
\hline www.olx.com.ng & 2.54 & 6 \\
\hline www.propertysearch.com.ng & 2.51 & 7 \\
\hline www.rightmove.co.uk & 2.27 & 8 \\
\hline www.propertyindex.com.ng & 2.26 & 9 \\
\hline www.lekkirealestatesales.com & 2.20 & 10 \\
\hline www.mobofree.com & 1.95 & 11 \\
\hline
\end{tabular}

It is pertinent to note that while 'Nigeria Property Centre' ranked $1^{\text {st }}$ in Table 5 , the mean score of this finding (3.87) remains lower than that of the 'To Let/For Sale' board which showed a mean score of 4.70 in Table 3 . The low mean score values were similarly found with all other property-based websites investigated in this study. These low mean scores indicate that ESVs have not entirely embraced property-based websites for marketing real estate in Lagos. The findings from this study coincide with study done Bond et al. (2000). This study relates to the limited adoption of property-based websites to the cost incurred from using them. It also relates it to the absence of a 
specific program set up by the NIESV/ESVARBON for training professionals on the use of the websites.

\section{Difference between the Adoption of Traditional and Contemporary Methods of Marketing}

An analysis was conducted to determine whether the established disparity in the use of traditional and contemporary methods of marketing amongst ESVs outlined above was statistically significant. The null hypothesis that 'there is no significant difference in the use of traditional and contemporary methods of marketing amongst ESVs in Lagos' metropolis, was formulated. To test the hypothesis, One Way Analysis of Variance (ANOVA) was adopted as presented in Table 6.

Table 6: ANOVA for the use of marketing methods

\begin{tabular}{|l|l|l|l|l|l|l|l|}
\hline & $\begin{array}{l}\text { Sum of } \\
\text { square }\end{array}$ & Df & $\begin{array}{l}\text { Mean } \\
\text { square }\end{array}$ & F & $\begin{array}{l}\text { P } \\
\text { value }\end{array}$ & Sig. & Decision \\
\cline { 1 - 5 } $\begin{array}{l}\text { Between } \\
\text { groups }\end{array}$ & 12.260 & 29 & 0.423 & 4.544 & 0.000 & $\mathrm{~S}$ & $\mathrm{H}_{1}$ accepted \\
\cline { 1 - 4 } Within \\
groups & 4.838 & 52 & 0.093 & & & & \\
\cline { 1 - 5 } Total & 17.098 & 81 & & & & & \\
\hline
\end{tabular}

From Table 6, F Statistics equals 4.544 and the p value is 0.000 . At $95 \%$ confidence level, the observed $\mathrm{p}$ value of $0.000<0.05$. This finding indicates the probability of the calculated $\mathrm{F}$ ratio resulting from chance is less than 0.05 $(\mathrm{p}<0.05)$. This implies that the null hypothesis could be rejected in this study. The alternative hypothesis that a significant difference in the usage of traditional and contemporary methods of marketing amongst ESVs exists, was therefore supported. Based upon these findings, ESVs in Lagos' metropolis were found to still employ conventional methods of real estate marketing more widely than property-based websites.

\section{Conclusion}

Today, the ubiquitous use of the internet provides increased opportunities for business marketing activities to reach out to their prospective clients/customers. Estate surveyors and valuers in Nigeria are currently not permitted to advertise/market their services or real estate products in innovative manners as limited by ESVARBON/NIESV regulations. However, the emergence of property-based websites continues to change the environment for real estate marketing in the current global context. This study appraised the response of estate surveyors and valuers in adopting this new phenomenon in marketing real estate within the Lagos' metropolitan area. It was revealed that conventional methods of marketing are still widely used by estate surveyors and valuers. It was further revealed that the property-based websites have not been fully embraced by estate surveyors and valuers, resulting in the limited optimisation of these contemporary opportunities. The low acceptance and implementation of property-based websites by ESVs for marketing real estate weakens the practice of estate agency in Nigeria in 
relation to today's globalised world. The outcomes of this study could assist in drawing the attention of Estate Surveying and Valuation Firms in Nigeria to the need to adopt property-based websites for improved performance in agency practice. In order to reach out to more prospective clients, it seems paramount that estate surveyors and valuers adopt a paradigm shift to the increased use of property-based websites for the marketing of real estate to better both agency practice and service delivery in firms. Also, a strategically structured and robust Mandatory Continuing Professional Development (MCPD) programmes targeted at educating Estate Surveyors and Valuers about the potentials of property-based websites in estate agency should be brought forward by NIESV/ESVARBON. This training will further increase their awareness, operations and benefits with the various forms of propertybased websites.

\section{Acknowledgements}

The authors would like to thank the surveyed firms for deeming it fit to respond to the study.

\section{References}

Agboola, A., Ojo, O. \& Amidu, A. (2010). The ethics of real estate agents in emerging economies: A cross-sectional survey of agents and service consumers' perception in Nigeria. Property Management, 28(5), pp.339-357.

Ajayi, O.M., Ajayi, O., Akinsiku, O. \& Osunsanmi, T. (2016). Strategies for housing affordability in Nigeria. Journal of construction project management and innovation, 6(1), pp.1620-1632.

Almalki, S. 2016. Integrating quantitative and qualitative data in mixed methods research challenges and benefits. Journal of education and learning, 5(3), pp.288-296.

Araloyin, F. M. \& Olatoye O. (2011). An analysis of real estate consumers' perception of service quality in estate agency practice in Lagos

Metropolis, Nigeria. Journal of Economics and International Finance, 3(3), pp.139-145.

Ayedun, C., Oloyede, S., Oluwunmi, A, \& Oyedele, M. (2014). The effect of marketing strategies on corporate performance of estate surveying and valuation firms in Kaduna Metropolis of Nigeria. American International Journal of Social Science, 3(4), pp.202 -209.

Babawale, G. K. (2011). Variance in residential property valuation in Lagos, Nigeria. Property Management, 29(3), pp.222-237.

Baen, J. S. \& Guttery, R. S. (1997). The coming downsizing of real estate implications of technology. Journal of Real Estate Portfolio Management, 3(1), pp.1-18.

Baldi, F. (2013). Valuing a greenfield real estate property development project: a real options approach. Journal of European real estate research, 6(2), pp.186-217.

Benjamin, J. D. \& Chinloy, P. T. (1995). Technological innovation in real estate brokerage. Journal of Real Estate Research, 10(1), pp.35-44. 
Bobenko, N. A. (2013). A comprehensive approach to selling real estate. Condominium Realty Ltd. Available: http://www.dwellinoc.com/files/5/Marketing (2015, September 22).

Bond, M., Seiler, M., Seiler, V., \& Blake, B. (2000). Uses of websites of real estate marketing. Journal of Real Estate Portfolio Management, 6(2), pp.203-211.

Blaikie, N. (2010). Designing Social Research. Journal of sustainable development and management, 2(3), pp.34-45.

California Association of Realtors. (2013). Home Buyer Survey. Los Angeles: Research and Economics.

Cherif, E. (2013). Analysis of the internet impact on the real estate industry. International journal of service science, management, engineering and technology, 4(3), pp.17-22

Creswell, J. W. (2009). Research design: Qualitative, quantitative, and mixed method approaches. $3^{\text {rd }}$ ed. Thousand Oaks, CA: Sage Publications.

Crowston, K. \& Wigand, R. (1999). Real estate war in cyberspace: an Emerging electronic market. International Journal of Electronic Markets, 9(1- 2), pp.1-8.

Iroham, C. O., Oluwunmi, A. O., Ayedun, C. A. \& Oloyede, S. A. (2012). An investigation of the efficiency in Nigeria real estate agency practice. Mediterranean Journal of Social Sciences, 2(2), pp.184-193.

Iroham, C. O., Oloyede, S. A., Ajibola, M. O. \& Durodola, O. D. (2014). Towards an effective real estate agency education: A stride to efficiency. Procedia social and behavioural sciences, 191(14), pp. 2687-2692.

James, E., Yeqing, B. \& Don L. (2000). Internet real estate information: Are home purchasers paying attention to it? Journal of Consumer Marketing, 17(7), pp.575-590.

Kotler, P. \& Armstrong, G. (2012). Principles of Marketing. $14^{\text {th }}$ ed. New Jersey: Prentice Hall.

Kumar, R. (2011). Research methodology a step by step guide for beginners. $3^{\text {rd }}$ ed. Thousand Oaks, CA: Sage Publications.

Kvedaraviciene, I. (2009). Real estate market dynamics in the context of changing economy. ISM University of Management and Economics, Lithuania.

Ley, D. (2015). Global China and the making of Vancouver's residential property market. International Journal of Housing Policy, 17(1), pp. $15-34$.

Mangold, W. G., \& Faulds, D. J. (2009) . Social Media: The new hybrid element of the promotion mix. Business Horizons, 52(4), pp.37365.

McDonagh, J. (2006). Trends in the use of the internet for marketing Residential real estate in New Zealand. Available: http://www.prres.net/papers/McDonagh_Trends_in_the_use_of the Internet.pdf [2017, December 12]

NIESV. (2009). Directory of estate surveyors and valuers. The Nigerian Institution of Estate Surveyors and Values.

Olukolajo, M., Ojo, B., \& Akinwamide, D. (2015). Assessment of use of social media in real estate transactions in Lagos property market. American Journal of Economics, Finance and Management, 1(2), pp. 
63-68.

Oni, A. (2013). Digital divide-a challenge to the real estate practice in Nigeria? Property Management, 31(1), pp.22-38.

Oni, A. \& Adebayo, M. (2012). Challenges facing sustainable real estate marketing and practice in emerging economy: case study of Nigeria. International Journal of Marketing Studies, 4(1), pp.58-67.

Rogers, D. \& Koh, S. Y. (2017). The globalisation of real estate the politics andpractice of foreign real estate investment. International journal of housing policy, 17(1), pp.1-14.

Schulte, K., Rottke, N \& Pitschke, C. (2005). Transparency in the German Real estate market. Journal of Property Investment and Finance, 23(1), pp.90- 108.

Scott, D. M. (2013). The New Rules of Marketing \& PR: How to use Social Media, Online Video, Mobile Applications, Blogs, News Releases, and Viral Marketing to Reach Buyers Directly. New Jersey: John Wiley \& Sons.

Skitmore, M. \& Smyth, H. (2006). Pricing construction work a marketing viewpoint. Available: http://discovery.ucl.ac.uk/4640/1/4640.pdf. [2017, November 12].

Thrall, G. I. (1998). Real Estate Information Technology: The Future is Today,In Gilbert, H.C. III. ed., GIS in Real Estate, Appraisal Institute, Chicago Illinois, pp.165-74.

Yankah, J. E. \& Dadzie, D. K. (2015). Marketing construction business: problems, prospects and strategies. European journal of business and management, 7(9), pp.182-192. 